Natalija Žalec

Andragoški center

Slovenije

\section{IZOBRAŽEVANJE IZOBRAŽEVALCEV \\ ODRASLIH TEMELINA NALOGA \\ SODOBNE IZOBRAŽEVALNE POLITIKE \\ PRI NAČRTOVANJU VSEŽIVLJENJSKEGA UČENJA}

\section{POVZETEK}

V zadnjih nekaj letih v Evropi vse bolj glasno razmišljamo o izobraževanju izobraževalcev, a tokrat ne le o učitelijh v šolah, Wpas sirse - o izobraževalcih, ki delujjejo zunaj šolskih programov izobraževanja, npr. na širokem področju poklicnega kot neformalnem. V razpravi se posvečamo predvsem usposabljanju in spopolnjevanju izobraževalcev odraslih v Sloveniji skozi ugotovite, do katerih so prišli raziskovalci v Evropi kot tudi v Sloveniji. Razpravljamo o njihovem položaju, vlogah in nalogah, o tem, kaǩsne kompetence potrebujejo in kakšne so njihove izobraževalne potrebe.

Ključne besede: izobraževalci odraslih, andragoški delavci, izobraževanje odraslih, organizator dela, kompetence izobraževalcev odraslih, karierni vzorci izobraževalcev odraslih, identiteta izobraževalcev odraslih, izobraževalne potrebe izobraževalcev odraslih

EDUCATION OF THE ADULT EDUCATORS - BASIC AIM OF THE MODERN EDUCATION POLITICS IN PLANING LIFELONG LEARNING - ABSTRACT

The problem of train the trainers becomes the important subject of broader debates in the field of education - not only of those of formal youth education, but also of those educators who work in non-formal education and adult education. the latest results of European and Slovenian studies at the field. The emphases are positions and types of adult lerning staff, the roles and the tasks, competences and learning needs.

Keywords: adult educators, types of of adult learning staff, career path, identity of adult educators, learning needs, competences of adult teaching staff.

V zadnjih nekaj letih v Evropi vse bolj glasno razmišljamo o izobraževanju izobraževalcev, a tokrat ne le o učiteljih $\mathrm{v}$ šolah, ampak sirš - o izobraževalcih, ki delujejo zunaj šolskih programov izobraževanja, npr. na področju pollicega usposablja ja in spopolnjevanja, predvsem pa tudi tistih, ki delujejo na področju izobraževanja odraslih - tako formalnem kot neformalnem. $\mathrm{V}$ tej razpravi se bomo posvetili predvsem slednjim. Delavce izobraževanju odraslih strokovno imenujemo z enotnim izrazom izobraževalci odraslih ali tudi andragoški delavci - primerjaj Jelenc (1991: 21). Skozi ugotovite, do katerih so prišli tako raziskovalci v Evropi kot tudi v Sloveniij, bomo razmišljali o njihovem položaju, vlogi, ki jo opravljajo v družbi znanja, in o nalogah, ki jo sestavljajo, predvsem pa o tem, kakšne kompetence potrebujejo, da bi jih uspešno opravili, in kakšne izobraževalne potrebe imajo.

\section{PODROČIA DELOVANIA}

IZOBRAŽEVALCEV ODRASLIH

Uporaba izraza izobraževalec odraslih pri bralcu gotovo sproži veliko različnih asociacij. Ali imamo v mislih osebo, ki si je pred leti pridobila naziv univerzitetni diplomiran andragog, ali nekoga, ki poučuje odrasle v srednjem poklicnem izobraževanju, morda tečaju tujega jezika ali računalništva, v programih opismenjevanja? Je to univerzitetn profesor, ki poučuje študente ob delu po univerzitetnem programu, ali mentor doktorandu naravoslovnih znanosti, ali mentor zdravniku specializantu, ki opravlja staž na enem od boltni portal, ali pa urednic tliti odrasle ljudi, da bi bolj varčno ravnali energetskimi viri? Je to svetovalec $\mathrm{v}$ svetovalnem središču za izobraževanje odraslih ali organizator izobraževanja na ljudski univerzi ali srednji šoli, njena direktorica, mentor $\mathrm{v}$ študijskem krožku univerze za tretje življenj obdobje ali kadouski delavec v podjeju, ki pripravlja načrt izobraževanja zaposlenih, al oseba, ki uvaja novega sodelavca na delovno mesto, ali nekdo, ki nudi učno pomoč skozi javna dela?

Ta zajetni sklop retoričnih vprašanj, ki si jih lahko zastavimo ob prosti asociaciji, opozarja na to, kako zelo razvejeno je učenje in izobraževanje odraslih in kako zelo različne vloge opravljajo tisti, ki se posvečajo problemom izobraževanja odraslih $\mathrm{v}$ različnih okoliščinah. Študija Poklici v izobraževanju odraslih v Evropi - Adult Education Professions in Europe (2008), v kateri je sodelovalo 30 evropskih držav, med njimi tudi Slovenija, je na področju neformalnega in nepoklicnega izobraževanja odraslih identificirala široko paleto različnih delovnih položajev in znotraj teh več različnih vlog, tudi poklicev ter nalog, ki jih opravljajo zaposleni na tem področju. Strnjeno jih povzemamo v tabeli na naslednji strani.
Pomembno vprašanje, ki se nam tu postavi, je, kako in v kakšnem obsegu nekdo opravlj delo izobraževalca odraslih - je to vzporedn ali občasna vloga ali pa glavna in permanentna? Pomembno je tudi, ali ta oseba sodeluje le neposredno $z$ učečim ali pa se mora povezovati širše in opraviti razen poučevanja ožjem smislu tudi druge naloge, da bi lahko obraževanjem. Sprehod skozi vloge, ki st jih nanizali v prejšnjem odstavku, nam pove, da so nekatere vloge glavne in sestavljajo jedro nekogaršnje poklicne kariere (npr. organizator izobraževanja na ljudski univerzi), druge pa pomenijo le manjši del dela, ki ga nekdo izvaja znotraj ali ob svoji temeljni poklic dejavnosi delovnem mestu. Onenjena evropsa raziskava je pokazala, da izobraževalci na področju neformalnega in nepoklicnega izobraževanj večino dela opravijo honorarno - večinoma tudi kot dodatno vlogo ob temeljni poklicn dejavnosti. Podobno ugotavljamo tudi v Sloveniji (Birman Forjanič idr., 2008), ne le za neformalno in nepoklicno, ampak tudi za formalno izobraževanje odraslih.

\section{POLOŽA IN IDENTITETA}

IZOBRAŽEVALCEV ODRASLIH IN DEIAVNOSTI IZOBRAŽEVANIA

\section{ODRASLIH}

V fokusni skupini (Žalec in Đorđević, 2009), ki smo jo o izobraževanju izobraževalcev odraslih v Sloveniji izpeljali na Andragoškem centru Slovenije, se je pokazalo, da je s tem, ali je vlog izobraževalca odraslih jedro ali le del oz. dopolnilo poklicni dejavnosti, ki je nekdo opravlja, povezana tudi njegova identifikacija $\mathrm{z}$ vlogo in razmišljanje o njegovih izobraževalnih potreba na tem področju. Izk na ten podrocju. Izkaza se je, da je strokovn identifkacija pri posancznikh, ki jogo izobraževalca odraslih opravljajo kot del ali dopolnilo svoji temeljni poklicni dejavnosti, pogosto zelo šibka ali je skorajda ni. Univerzitetna učitelji- 


\begin{tabular}{|c|c|c|}
\hline POLOŽAJ IZOBRAŽEVALCA & VLOGE (VČASIH TUDI POKLICI) & NALOGE \\
\hline Poučevanje & $\begin{array}{l}\text { Učitelj, tutor, trener, inšrtruktor, } \\
\text { mentor }\end{array}$ & $\begin{array}{l}\text { Poučevanje, usposabljanje, urjenje; } \\
\text { tudi mentorstvo, svetovanje, vodenje } \\
\text { svetovanca skozi kariero }\end{array}$ \\
\hline Upravljanje in vodenje & $\begin{array}{l}\text { Lahko so splošne, npr. direktor } \\
\text { izobraževalne organizacije, ali } \\
\text { specifične: komercialist, piarovec, } \\
\text { kadrovik }\end{array}$ & $\begin{array}{l}\text { Vodenje podjetja, stiki z javnostmi, } \\
\text { trženje, razvoj človeških virov }\end{array}$ \\
\hline Svetovanje in vodenje & $\begin{array}{l}\text { Svetovalec za kariero, osebni sveto- } \\
\text { valec, pomočnik pri učenju }\end{array}$ & $\begin{array}{l}\text { Svetovanje za kariero, svetovanje in spre- } \\
\text { mljanje posameznika skozi učni proces, } \\
\text { osebno svetovanje }\end{array}$ \\
\hline $\begin{array}{l}\text { Načrtovanje izobraževalnih } \\
\text { programov in programiranje }\end{array}$ & $\begin{array}{l}\text { Le redko definirano kot poseb- } \\
\text { na vloga, večkrat kot del drugih } \\
\text { vlog - največkrat menedžmenta in } \\
\text { učiteljev }\end{array}$ & $\begin{array}{l}\text { Razvoj in priprava ustreznih programov } \\
\text { in gradiv za in v podporo učenju }\end{array}$ \\
\hline Podporne dejavnosti & $\begin{array}{l}\text { Receptor, referent v sprejemni pisar- } \\
\text { ni/referatu, informator, administra- } \\
\text { tivno osebje }\end{array}$ & $\begin{array}{l}\text { Sprejem strank in usmerjanje, informi- } \\
\text { ranje o vsebini in pogojih za vključitev v } \\
\text { program, vpis v programe }\end{array}$ \\
\hline Uporaba medijev & $\begin{array}{l}\text { Helpdesk menedžr, sistemski me- } \\
\text { nedžer (upravljavec sistema) }\end{array}$ & $\begin{array}{l}\text { Zagotavljanje tehnične pomoči osebju in } \\
\text { udeležencem, npr. pri študiju na daljavo; } \\
\text { upravljanje in vodenje osebja za učin- } \\
\text { kovitejše delovanje medijsko podprtega } \\
\text { sistema; skrb za stranke }\end{array}$ \\
\hline $\begin{array}{l}\text { Usposabljanje izobraževalcev } \\
\text { odraslih' }\end{array}$ & $\begin{array}{l}\text { Vse predhodne funkcije: poučeva- } \\
\text { nje, menedžment, svetovanje, pro- } \\
\text { gramiranje, podpora }\end{array}$ & $\begin{array}{l}\text { Prevladujoče naloge pri vodenju področja: } \\
\text { načrtovanje, programiranje, koordinacija, } \\
\text { supervizija, spremljanje in evalvacija }\end{array}$ \\
\hline
\end{tabular}

ca, ki v svoji izobraževalski praksi poučuje tudi študente ob delu, se je denimo šele v fokusiran razpravi poistovetila tudi $\mathrm{z}$ vlogo izobraževalke odraslih, pred tem pa se je vabilu na razpravo odzvala s položaja strokovnjakinje za področje, ki ga raziskuje in razvija, in svoji dnevni vpetosti $\mathrm{v}$ andragoško delo za kakovost razprave ni pripisovala večjega pomena.

Podobno smo ugotavljali tudi v študiji (Birman Forjanič, 2008), opravljeni na vzorcu 520 izobraževalcev odraslih, ki imajo različne vloge izobraževanju odraslih. Zajeli smo tiste, ki se pogosto spopolnjujejo na Andragoškem centru Slovenije, in tiste, ki se naših programov ne udeležujejo, saj nas je med drugim zanimalo, zakaj je tako. Pri učiteljih v programih poklic strokovnega iz najpogostejo vlogo, se je pokazalo, da se od vseh vlog najmanj pogosto izobražujejo na Andragoškem centru Slovenije. Kot glavni vzrok se je razkrilo to, da ponudbo slabo ali sploh ne poznajo (tako je odgovorila več kot polovica), ker so o njej slabo obveščeni. Tudi tisti, ki se izobrǎ janj na Andragošem centru Slovenije udeležuje, so za ponudbo izvedeli udeležujo, so za ponch izver straneh centra ali iz brošure, kjer je prikazan ponudba. Le slabo četrtino je o tem obvestila oseba, ki v organizaciji koordinira dejavnosti, povezane z izobraževanjem odraslih. Sklepamo lahko, da se izobraževalci odraslih praviloma sami odločajo o tem, kje in kako se bodo izobraževali, in da jim organizacija, kjer opravljajo delo izobraževalca odraslih, te ponudbe večinoma ne posreduje. Hkrati s tem se je izkazalo, da bi o ponudbi želeli biti bolje obveščeni in da b bila zanje najustreznejša dva načina obveščanja: neposredno na njihov elektronski naslov ali pa posredno na naslov koordinatorja izobraževanja odraslih v izobraževalni organizaciji. Iz slednjega lahko sklepamo, da od organizacije, kjer opravjajo andragošo delo, pričkujejo tudi, da poskrbi za stalno strokovno spopolnjevanje osebja na področju izobraževanja odraslih.

Zanimalo nas je, kako definirajo znanje, ki ga potrebujejo pri svojem delu $\mathrm{v}$ izobraževanju odraslih, zato smo jih vprašali, kako pomembno se jim zdi andragoško znanje za opravljanje tega dela. Velika večina vprašanih meni, da je za opravljanje njihovega dela na področju izobraževanja odraslih andragoško znanje enako, za nekatere pa celo bolj pomembno od znanja iz njihove temeljne stroke. Tako je odgovorilo več kot 90 odstotkov pano, da prihajajo iz razlicnih, predvsem neandragoških stok, z zadř̌com pa tudi, da pri sebi prepoznavajo potrebe po izobraževanju na tem področju. Vprašanje pa je, koliko tem potrebam zadostijo oz. kako poskrbijo za njihovo zadovoljitev. Zato nas je zanimalo, kje spopolnjujejo svoje andragoško znanje.

Izbrali so lahko več odgovorov. Večina, skora 70 odstotkov, je odgovorila, da se spopolnjuje $\mathrm{v}$ organizaciji, kjer opravlja andragoško delo drugo mesto je pripadlo Andragoškemu centru Slovenije, temu so sledili strokovni posveti in mednarodni projekti, medtem ko so udeležbo v drugih oblikah organiziranega učenja - npr. n - e edko avaji. Iz odgovoro ni racija kaǩn izob̌ali. Iz odgovorov ni razvidno, kakšno izobraževaje poteka znotraj izobraževalnih organizacij, kjer vprašani opravljajo andragoško delo, zato v resnici ne vemo, ali gre za organizirane oblike učenja, samoizobraževanje v neorganiziranih oblikah ali kaj drugega. Tudi ne moremo presojati o vsebini tega izobraževanja, zato nam kakovost spopolnjevanja andrago-

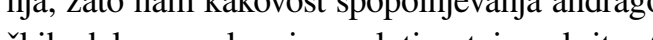
nej smo poskršli sklepati posredno na podla vzorca analiz izobraževalne ponudbe bolj vidnih izobraževalnih organizacij, ki je javno prikazana za ciljno skupino izobraževalcev odraslih - npr univerza, nekatere izobraževalne organizacije, $\mathrm{k}$ to ponudbo posebej oglašujejo

Ob pregledu smo ugotovili, da je ta v primerjavi s ponudbo za izobraževalce, ki poučujejo mladino, skromna, enolična, razdrobljena, predvsem pa slabo pregledna. Ti podatki nam ob še nekaterih drugih ugotovitvah - slabo razvite možnosti kariernega razvoja, napredovanja, nerazvit 
Izobraževalci odraslih praviloma sami odloćajo o tem, kje in kako se bodo izobraževali in spopolnjevali.

sistemizacija delovnih mest - govorijo o položaju izobraževalcev odraslih $\mathrm{v}$ celotnem sistemu vzgoje in izobraževanja. To gotovo vpliva tudi na identiteto in identifikacijo izobraževalcev odraslih in na njihovo pripravljenost za izobraževanje na tem področju.

V intervjujih (Možina in Birman Forjanič, 2009) $\mathrm{z}$ vodji izobraževanja odraslih, organizatorji izobraževanja oz. vodji programskih področij, ki izvajajo izobraževanje odraslih na ljudskih univerzah, srednjih šolah in zasebnih izobraževalni organizacijo zatoria izobr

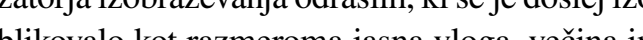

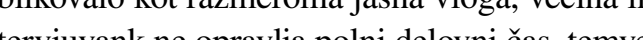
tervjuvank ne opravlja polni delovni čas, temvec da razen tega še poučujejo oz. opravljajo druge naloge, ki jih neposredno ne prištevajo $\mathrm{k}$ vlog organizatorja.

z odgovorov teh, ki so zaposlene na šolah, smo lo ko izǔ̌ili, da je izobraževalna dejavnost odrasle (izredno izobraževanje) le izjemo

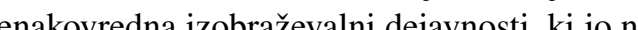

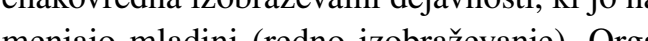
menjajo mladini (redno izobraževanje). Organizatorji se neredko srečujejo s problemi, ki so povezani z manjšo pripravljenostjo honorarni učiteljev za sodelovanje pri skupnih dejavnostih - npr. izvedbeno načrtovanje, če te niso posebej finančno ovrednotene. Na to zapostavljenost dročja in vloge organizatorja opozarjajo tudi drugi podatki, ki smo jih dobili v intervjuju. Za 300 do 500 udeležencev izobraževanja odraslih je $\mathrm{v}$ organizaciji predviden le en organizator izobraževanja. Ta je odgovoren za večino nalog, ki so povezane z načrtovanjem dejavnosti, prilagajanjem programov, vodenjem, organizije tudi za svetovanje in izobraževanje osebja, ki izobražuje odrasle. $V$ najboljšem primeru mu pomaga le ena oseba v administraciji. Večina se pri svojem delu posveča predvsem organizaciji, za razvoj dejavnosti pa jim največkrat ne ostane dovolj časa. Na tem mestu se nam zdijo pomembna opozorila ki so jih intervjuvanke izraJizražale $\mathrm{z}$ besedami. »Razvojne dimenzije manjka ne zato, ker bi se ljudje, ki delajo na teh delovnih mestih, ne hoteli ukvarjati z razvojem ali da se ne bi zavedali pomembnosti razvojnega dela, ampak ob vsem drugem delu za to enostavno zmanjkuje časa.« (Možina in Birman Forjanič, 2009: 16.)

z diskurza sogovornic je bilo mogoče razbrati, da je izobraževanje odraslih razumljen kot dodaten tržni vir, katerega prihodek je navadno namenjen razvoju organizacije - npr. nakupu nove izobraževalne opreme, le manjši delež pa neposrednemu razvoju dejavnosti izobraževanja odraslih, med drugim tudi izobraževanju delavcev za to področje. anjem in koordinacijo podrocja, odgovoren pa

Del razlogov za slabo udeležbo učiteljev srednjega poklicnega in strokovnega izobraževanja v programih, ki jih Andragoški center Slovenije namenja izobraževalcem odraslih, tako gotovo nju kot $\mathrm{z}$ vlogo učitelja v izrednem izobraževanju, saj so možnosti za napredovanje in kariern razvoj boljše pri prvem. Zato se za to vlogo $\mathrm{v}$ drugih programih stalnega strokovnega spopolnjevanja na področju vzgoje in izobraževanja tudi bolj izobražujejo. Razumljivo je torej, da se učitelji manj identificirajo z vlogo izobraževalca odraslih in jo pogosto razumejo kot dopolnilo, ne pa kot enakovredno vlogi, ki jo opravljajo pri poučevanju mladine. Podobno razumejo dejavnost izobraževanja odraslih tudi v organizacijah, kjer izredno izobraževanje (izobraževanje odraslih) izvajajo poleg rednega izobraževanja (za mladino).
V nekaterih organizacijah je vloga organizatorja oz. vodje izobraževanja odraslih šibka (ilustrativen podatek: »Septembra in oktobra se nekdo z izobraževanjem odraslih ukvarja 100-odstotno med letom pa dve uri.« (Možina in Birman Forjanič, 2009: 14)). Čeprav govorimo le o enem primeru, je pomembno premisliti o tem, kakšen ja odraslih, posredno pa tudi izobraževanja odraslih, ko oseba na to delovno mesto ni bila "povabljena temveč je bila zanj »določena« oz. ga je bila prisiljena prevzeti, da je s tem dopolnila učno obveznost. $\mathrm{V}$ temu podobnih primerih bo to lahko vplivalo na njeno motivacijo za andragoško spopolnjevanje.

Čeprav zaradi nereprezentativnosti vzorca ugotovitev ne moremo posplošiti, nas ta študija primera na skupini 11 intervjuvank opozarja na pomembne vidike položaja izobraževalcev odraslih in tudi samega položaja izobraževanja odraslih. Pri tem želimo opozoriti na pasti tržne logike, ki je usmerjena predvsem na dobiček in $v$ tem smislu tudi krčenje sredstev, namenjenih za razvoj dejavnosti, ki med drugim vkl razvoj kadrov. Razprava v fokusnih skupinah (Žalec in Đorđević, 2009) je pokazala, da je večina problemov, s katerimi se danes ubada izobraževanje odraslih, tako tudi izobraževalne organizacije, interdisciplinarnih. Te probleme lahko učinkovito rešijo le timi. Posebna naloga izobraževalnih organizacij je vpeljava timskeg dela in klime sodelovanja, ki pa ju ne more biti, če delo opravlja le ena oseba.

\section{KARIERNI VZORCI}

\section{IZOBRAZZEVALCEV ODRASUIH}

Ugotavljamo, da imamo zelo malo zanesljivih podatkov o tem vprašanju. Podobno ugotavlja tudi že omenjena študija o poklicih v izobraževanju odraslih (Adult Learning Professions in Europe, 2009). Podobno kot v evropski študij smo tudi iz našega preiskovanja tega področja - skozi vodene intervjuje (Možina in Birman
Forjanič, 2009) in fokusne skupine (Žalec in Đorđević, 2009) - ugotovili, da je izhodiščn strokovna izobrazba izobraževalcev odraslih zelo raznolika. Praviloma se na tem delovnem mestu le redkeje pojavljajo strokovnjaki s strokovno izobrazbo s področja andragogike, pedagogike, psihologije. $\mathrm{V}$ naših intervjujih (MožiForjanič, 2009) smo odkr nobena od sogovornic izhodiščno - ko se nja od nja odraslih, ni bila po svojem osnovnem poklicu diplomirana pedagoginja oz. andragoginja. Kar nekaj je takšnih, ki prihajajo iz naravoslovnih ali tehniških poklicev Pri celotni skupini se je potrdilo tudi, da so intervjuvanke na področju izobraževanja odraslih opravljale več kot eno vlogo. P sedmih od 11 se razkriva karier vzorec: gre za osebe, ki so v iz Izobraževalna dejavnost za odrasle je redko enakovredna izobraževalni dejavnosti za mladino.

obraževalni organizaciji najprej poučevale (redna zaposlitev ali zunanje sodelavke), kasneje pa so prevzele mesto organizatorice oz. vod edraslih, v dveh primerih pa sta

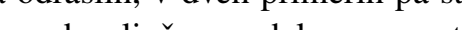
ravnateljice oz. pomočnice ravnateljice.

Zanimalo nas je tudi, kako in zakaj so prevzele to delo. Izkazalo se je, da je bila pri večini intervjuvank odločitev splet različnih okoliščin in naključij, ne pa načrtovanja. Pogosto navedeni razlog je: »V izobraževalni orga je spastlo delo $V$ izo besto vod je izobraževanja odrasiih zaradi odhoda $v$ pokoj. « Niti $v$ enem primeru ni bilo navedeno, da bi se oseba samoiniciativno prijavila na razpis za delovno mesto vodje izobraževanja odraslih. Večinoma jim je to delovno mesto ponudil ravnatelj oz. direktor, ko so že bile $v$ izobraževalni organizaciji kot učiteljice oz. so z njo sodelovale, ena je naved ji je za delovno mesto povedal kolega, ki je bi japoslen $v$ izo jeval zlogi, ki so jih udeleženke navijale za spejeje (a)

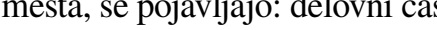
i omogoča več časa za družino, reden zaslužek, 
veselje do dela v izobraževanju odraslih, zaposlitev v izobraževalni organizaciji, ki je last staršev.

Ob tem se vprašamo, kakšno je izhodiščno znanje andragoških delavcev in kaj je vir znanja z opravljanje dela. Tudi če izhajamo iz tega, da si večina andragoških delavcev, ki ne prihajajo iz pedagoških smeri, pridobi pedagoško-andogopedagoskih smeri, ko izobrazbo, je ob vsej raznolikosti in hitre razvoju področja to vprašanje povsem primerno. Ob vsem tem, kar smo ugotavljali skozi razpravo, se nam utrne misel, da se izobraževalci odraslih izoblikujejo predvsem ob neposrednem delu in osebnih izkušnjah, ki si jih pridobijo pri svojem strokovnem delu. To se nam je posredno potrdilo tudi v naših intervjujih. Iz sporočil izpraževar do obraževalcer dom notranje/tiho znanje, ki so si ga pridobili s svojimi izkušnjami - največkrat iz položaja, ko so bili sami udeleženci ali učitelji, ki so sodeloval Z vodjo izobraževanja, ali pa so izhajali iz modela - pri eni intervjuvanki je bila to mama, $\mathrm{k}$ je bila strastna pedagoginja, pri eni pa starejša prijateljica, ki je opravljala delo na področju b̌rang

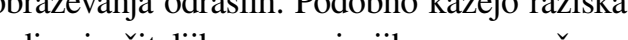
tudi pri učiteljih - vzorci njihovega poučevanja so zelo določeni z načini, ki so jih v odnosu do njih uporabljali njihovi učitelji.

Ta »kolektivna pedagoško-andragoška podzavest« nam po eni strani govori o tem, da je poučevanje, podobno kot učenje, antropolopola danost, ki ji je človek izpostavljen že od ojstva in jo skozi življenje nekako ponotranj in jo podobno kot druge ponotranjene vzorce vedenja nezavedno izraža v odnosu do drugih. Po drugi strani pa se moramo vprašati, ali je prav zaradi njene samoumevnosti vse prepogosto ne spregledamo kot strokovno opredeljene dejavnosti, ki se v praksi prilaam in se $\mathrm{v}$ kontekstu celotnega gaja razm dužbe tudi sama spreminja in vija ter je hkrai odločilen dejavik in razvija ter je hkrati odlocilen dejavnik in tu sredstvo za razvoj družbe. Ko govorimo o poučevanju, imamo seveda v mislih celovito pomoč pri učenju, ki jo zagotavljajo različni profili izobraževalcev odraslih, in s katero zajamemo vse dejavnosti andragoškega cikla, ki so povezane z ustvarjanjem pogojev, da bi drugemu pomagali pri učenju - od ugotavljanja izobraževalnih potreb do končne evalvacije učenja.

Ob vsem tem razmišljanju se seveda moramo vprašati, kakšna je kadrovska politika v izobraževanju odraslih, kakšne vzorce in merila je morda razvila, še posebno, ko se zavemo, da je le malo formalnih določil, ki bi to področje posebej urejala. Razmišljamo tudi o tem, kakšna sta transfer predhodno pridobljenega znanja in upoštevanje izkušenj izobraževalcev odraslih na drugih področjih izobreževanja Ali e kot se kazlikujejo od teh, ki si jih razvijejo izobraževalci, ki delujejo na drugih področjih (npr. učitelji v rednem izobraževanju, ravnatelji, šolski svetovalni delavci), in če se, kako in kateri dejavniki jih spodbujajo?

$\mathrm{V}$ zvezi s tem si seveda lahko zastavimo tudi vprašanje o standardih znanja, ki naj bi jih dosegali izobraževalci odraslih. Ali zadoščajo ti, ki jih okvirno z opredelitvijo stopnje izobrazbe, pridobljeno pedagoško-andragoško usposobljenostjo in strokovnim izpitom v svojem 92., 100. in 101. členu določa Zakon o organizaciji in financiranju vzgoje in izobraževanja (Uradni list RS, št 12/96, 23/96 in 108/2002) za celotno (23) morda prišel čas, da jih znova, predvsem pa bolj specifično opredelimo? Na vsa ta vprašanja v našem prispevku ne moremo odgovoriti, želimo pa spodbuditi razpravo o njih.

\section{NALOGE, KOMPETENCE IN \\ IZOBRAŽEVALNE POTREBE} skušali dobiti tudi v fokusnih skupinah (Žalec in Đorđević, 2009), ki smo jih izpeljali na An- dragoškem centru Slovenije. Zanimalo nas je, kakšna je vloga izobraževanja odraslih v sodobni družbi, kako se razvija andragoško delo kakšne kompetence potrebujejo izobraževalc odraslih in ali so v Sloveniji za to izpolnjen ustrezni pogoji. $\mathrm{V}$ razpravi so sodelovali različni strokovnjaki - univerzitetni profesorji in praktiki v izobraževanju odraslih, direktoji izvajalskih organizacij, člani združenj in društev na področju izobraževanja odraslih, kadrovski delavci. V nadaljevanju podajamo nekaj sinteznih ugotovitev o navedenih vprašanjih, ob katerih lahko pridemo do novih vprašanj, predvsem pa si moramo zastaviti konkretne naloge, da bi lahko ustrezno odgovorili na družbene potrebe po učenju.

Splošna ugotovitev razpravljavcev je bila, da izobraževanje odraslih sodi med jedrne dejavnosti sodobne družbe. Če so prejšnje družbe lahko ustvarile ločnico med izobraževanjem - šolanjem, ki naj bi bilo pripravljalnica za življenje, se v sodobni družbi znanja to zdi nemogoče. Učenje postaja del vsakdanjega življenja. Izobraževanje ni ločeno od dela in nemalokrat poteka v obliki reflektirane prakse, neformalnega poučevanja in širjenja spoznanj. $\mathrm{V}$ teh kontekstih vlogo pomočnika pri učenju vse bolj pogosto opravljajo ljudje, ki se za to delo niso posebej izobraževali ali usposabljali, čeprav je po drugi strani res, da sta kakovost učnega procesa in doseganje njegovega namena predvsem odvisna od tega, kako dobro je opravljeno andragoško delo.

Zato se nam kot sinteza zgornjega razmišljanja pojavi vprašanje, ali so ljudem poleg zmožnost učiti se učiti potrebne tudi zmožnosti poučevanja, če želijo biti dejavni v družbi. Ali torej postaja del kompetenc ki so bile nekoč opredeliene kot strove kompence izobract del splošne uspos del splosse usposobjenosti vseh strokovnjakov in vseh ljudi, ki želijo biti družbeno dejavni?

Naš odgovor je pritrdilen. Prav zaradi tega, ker andragoško znanje postaja tako splošno potrebno, je vprašanje usposabljanja za andraško delo še bolj aktualno in zahteva temeljit razmislek o tem, kako zagotoviti priložnosti za usposabljanje vsem, ki ga potrebujejo, oz. načrtno poskrbeti, da bo širjenje znanja $v$ različnih okoljih učinkovito in bo doseglo temeljni namen. Ugotavljamo namreč, da so inovacije in razvojni dosežki, ki ostajajo zaprti vozke strokovne kroge ali če niso podprti in rirše sprejeti v okolu, pr čemer je izobraže-

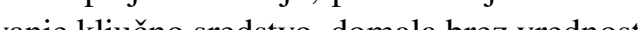
Spodbujanje in izobraževanje ter povezovanj so torej vzporedni proces tehnološkemu, kulturnemu in drugemu razvoju $\mathrm{v}$ družbi. $\mathrm{V}$ tem smislu je treba opredeliti tudi vlogo izobraževalcev. Opredeliti je treba njihove kompetence in razmisliti o ravneh njihove usposobljenosti glede na različne položaje, ki jih zavzemajo, predvsem pa, kako jim omogočiti, da se za te vloge usposobijo. Razmisliti moramo tudi o tem, katero je temeljno andragoško znanje, ki ga potrebujejo domala vsi, ki opravljajo vlogo izobraževalcev odraslih, katero pa je tisto, umestili pod kategorijo posebno poklicno znanje.

Nekateri razpravljavci so opozorili na težave, ki nastajajo pri delu, če izobraževalci odrasli niso ustrezno usposobljeni za izvedbo posameznih faz andragoškega cikla. To so denimo navajali pri ugotavljanju izobraževalnih potreb in načrtovanju programov. Ugotavljajo, da udeleženci - najsi bodo posamezniki naji podjetja in organizacije - pogosto ne znajo artikulirati svojih izobraževalnih potreb, po drugi strani p izobraževalci tudi niso usposobljeni, da bi jim pomagali pri njihovem opredeljevanju in izražanju. Gre za izrazito strokovno delo, ki ima svojo podlago v psiholoških, socioloških in pedagoško-andragoških disciplinah. Podobno je s prilagajanjem programov in pripravo posebnih konkretno učno skupino ali posameznika Na podobne probc ske so pri spremlya in eva procesa, kjer so poudarili predvsem to, da iz 
obraževalci evalvacijo sicer izpeljejo v smislu pridobivanja in obdelave podatkov, pozneje pa o teh podatkih ne razmislijo niti jih ne vzamejo za izhodišče za načrtovanje in izboljšanje andragoškega dela. To velja tako za organizacije kot za posamezne izobraževalce, npr. učitelje. Opozorili so na to, da se povečujejo naloge s področjj meneľ̌menta in administraije. Vse več ije in čsa je treba nameniti pridob energije in časa je treba nameniti pridobivanju finančnih in drugih sredstev za izobraževalno dejavnost, hkrati pa postajajo postopki vse bolj obremenjeni $\mathrm{z}$ administrativnim delom, npr. prijave na razpis, izpolnjevanje dokumentacije, za katerega izobraževalci izhodiščno niso usposobljeni.

Veliko potreb, ki so se jih zavedeli pri svojem delu, so nam sporočili tudi izobraževalci, ki so odgovarjali na naš anketni vprašalnik v letu 2008 (Birman Forjanič idr., 2008). Iz odgovorov anketiranih, ki so sodelovali v naši študiji, lahko ugotovimo, da njihove potrebe izhajajo iz:

potreb odraslih, za katere opravljajo andrago-

ško delo (temeljno andragoško znanje, različ

ne ciljne skupine, posebne potrebe udeležen-

cev, individualna obravnava udeležencev ...); značilnosti na novo nastajajočih učnih okolij (sodelovanje z okoljem, animacija za vključitev v izobraževanje, elektronsko učenje, oblikovanje gradiva);

potreb sodelovanja med izobraževalci (sodelovanje med učitelji, timsko delo, medpredme-

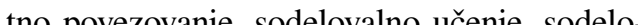
sodelo-

enih družbenih okoliščin (demografke spremembe, globalizacija, zakonodajne spremembe);

posebnosti razvoja delovnih nalog, ki jih opravljajo (npr. organizator izobraževanja, projekni menedžment, svetovanje v izobraževanju), in $\mathrm{s}$ tem povezanih kompetenc.

Iz tega ugotavljamo, da je izobraževanje odraslih področje, kjer se srečuje veliko različnih disciplin in strokovnjakov, ki se med seboj pomembno razlikujejo. Ob tem jih kot izobraževalce odraslih povezujejo skupni cilji. Pri doseganju teh si prizadevajo za skupno metodologijo dela, 列 razviti podobne kompetence.
Na vprašanje, katere so glavne naloge in temeljne zmožnosti, ki si jih morajo pridobiti andragoški delavci, so razpravljavci v fokusnih skupinah navedli naslednje:

- sestavljanje in prilagajanje izobraževalnih programov,

- podpora udeležencem pri učenju: motivacija, svetovanje, osebno načrtovanje učenja,

zagotavljanje celovite kakovosti dela zaposlenih v izobraževalni organizaciji,

- timsko delo,

- evalvacija vzgojno-izobraževalnega procesa,

- zagotavljanje finančnih sredstev,

- obvladovanje dokumentacije.

Razprava je pokazala, da so s temi nalogami neposredno povezane tudi kompetence in izobraževalne potrebe izobraževalcev odraslih. Potrebe po usposabljanju izobraževalcev odraslih se odpirajo na številnih področjih, če hočejo ti kakovostno opraviti svoje delo.
Iz vseh odgovorov, ki smo jih dobili v naših študijah, lahko izluščimo pomembno sporočilo, da izobraževanje in stalno spopolnjevanje izobraževalcev odraslih postajata vitalen del vsake vloge, ki jo opravljajo izobraževalci odraslih. To spoznanje je treba upoštevati tudi pri načrtovanju kadrovske politike in opredeljevanju posameznih vlog v izobraževanju odraslih ter ne nazadnje pri načrtovanju politike izobraževanja v državi.

Na tem mestu želimo opozoriti, da v slovenskem prostoru nismo vzpostavili celovitega spremljanja podatkov o programih andragoškega spopolnjevanja. Vsebine andragoškega spopolnjevanja se v različnih klasifikacijah pogosto skrivajo pod širšimi tematskimi sklopi - npr. drǔ̌boslovje,

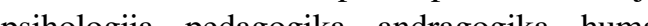
psihologija, pedagogika, andragogika, humanistika -, zato bi v prihodnje vsekakor veljalo razmisliti, kako celovito, usmerjeno in načrtno pridobivati in spremljati podatke o vsebinah andragoškega usposabljanja pri različnih ponudnikih. Glavni namen tega je, da bi laže ugotavljali potrebe po razvoju novih vsebin in programov usposabljanja in spopolnjevanja, ki bodo neli na sodbben - kompetenčno za neli na sodoben - konpetenčno zasnovanen modelu, preglednosti izobraževalne ponudbe in prepoznavnosti njenih izvajalcev ter posledič nem prizadevanju za odličnost ponudbe in omogočanje razvoja kariere strokovnih delavcev na različnih področjih razvijanja človeških virov, med katerimi je dejavnost izobraževanja in učenja odraslih gotovo zelo pomembna.

Ugotavljamo tudi, da bi bilo področje izobraževanja izobraževalcev odraslih treba raziskati. $Z$ razvojem andragoškega dela in različnih profilov izobraževalcev odraslih, vsebino in obsegom različnih nalog, ki jih ti opravljajo, se namreč nihče načrtno ne ukvarja. Prav tako so slabo raziskani karierni vzorci in izobraževalne potrebe izobraževalcev odraslih, na kar smo v naši razpravi že opozorili. Tako fokusne skupine kot pogovori z organizatorji izobraževanja odraslih, pa tudi odgovori vprašanih v študiji, ki jo je Andragoški center Slovenije opravil v letu 2008, ka- žejo na to, da imajo izobraževalci odraslih man važnosti in priložnosti, da bi zadostili izobraže valnim potrebam, ki jih prepoznajo pri sebi. Tud raziskave o položaju in usposobljenosti izobraževalcev odraslih (Adult Learning Professions in Europe, 2008), ki so bile v zadnjih nekaj letih opravljene v Evropi, so pokazale podobno. Pri udeleženest izobră̌valcev v izobry̌evaju so prav izobraževalci odraslih najbolj podhranjena skupina. Še posebno to velja za številne izobraževalce, ki delujejo na področju neformalnega in nepoklicnega izobraževanja.

Paul Balanger, predsednik Mednarodnega sveta za izobraževanje odraslih ${ }^{2}$ (ICAE - The International Council for Adult Education), je v slavnostnem govoru (European Association for The Education of Adults, 2009), ki ga je imel v Bonnu junija 2009 ob podelitvi enega od priznanj EAEA, opozoril, da je skrb, ki jo politike namenjajo izobraževanju odraslih, še zmeraj prem jhu Trasil se zmen premajhna. Tud najpomembnejse razvojne organizacije, kot je denimo Evropski razvojni sklad, pri svojih pro-

gramih in razpisih pozabljajo na koncept vsež vljenjskega učenja, predvsem na izobraževaln potrebe odraslih, in domala vso svojo pozornos in sredstva namenjajo formalnemu sistemu izobraževanja mladih. Balanger opozarja na to, da vseživljenjsko učenje ni ideološko vprašanje, ampak stvarna potreba, ki je utemeljen na človekovih pravicah in človekovi potreb po samouresničevanju, na drugi strani pa izhaja iz zahtev in potreb razvoja družbe in njenih vitalnih področij (npr. gospodarstvo, znanost, na to, da bodo mladi dozoreli, se izobrazili in začeli reševa probleme, s katerimi se stečue mo že dans. Glavna ali vsa enakovedna ske the ski sistemov morajo torej posta 
izobraževanje odraslih ne glede na kontekst, v katerega je postavljeno, Balanger opredeljuje treh alinejah:

40 odstotkov odraslih ne izraža svojih izobraževalnih potreb,

- »kultura strahu«, ki je posledica hitrih sprememb, izgube in nestalnosti položaja posameznika v družbi - pri odraslih se kaže kot strah pred spreminjanjem zahtev, ki jih bodo morali izpolniti in za katere morda niso ustrezno usposobljeni;

neučinkoviti odgovori institucij in družbenih sistemov - med njimi tudi izobraževalnega sistema - na novonastale družbene razmere in potrebe.

To so poglavitni problemi izobraževalcev odraslih. Štirideset odstotkov odraslih, ki ne govori o svojih izobraževalnih potrebah - bodisi ker jih ne prepozna bodisi ker jih ne zna izraziti, se v povezavi s kulturo strahu in vrsto neustreznih sistemskih odgovorov spremeni v resno grožnjo sodobni civilizaciji in demokratični oz vključujoč družbi ter tudi družbi znanja. Izobraževanje odraslih ima pri preseganju tega položaja pomembo vlogo. Pomembno vprašanje za izobraževalce odraslih pri tem je seveda, ali se izobraževalci teh problemov zavedajo in ali so usposobljeni za njihovo reševanje. Ali jih izobraževalni sistem pri tem podpira oz. ali jih sistem sploh preponava kot pomembne sodelavce in izpolnjuje tudi pogoje za njihovo delo? Med drugim tudi tako, da jim zagotavlja možnosti za spopolnjevanje strokovnega znanja. Nujno je torej, da postane izobraževanje izobraževalcev odraslih nihova lastna skrb, skrb izobraževalnih organizacij, kjer delujejo, predvsem pa tudi skrb zobraževalne politike.

1 Raziskovalci opozarjajo, da ta položaj izobraževalcev v odgovorih respondentor na začetku ni bil eksplicitno naveden. Poznejsere razprave ekspertov so pokazale, da ta položaj ni bil omenien, ker nanj, ko so razmišljali o položajih praktikov v izobraževanju odraslih, sprva niso pomislili. Opozariajo tudi na to, da je bilo tudi v razpra- vah prav ob tem polozajui in vlogah veliko nejasnosti in
da je več kot 50 odstotkov vseh vprašnnih izvajalcev izobră̌evanja odraslih odgovorilo, da tega položaja v njihovi organizaciii nihče ne zaseda - nihče se ne ukvarja zizobrazevanjem osebja. Ob tem bi bilo vredno razmisliti, kako izobrazevevalci odrasih sami pri sebi razumejo sooj polozaj v izobrazevanju odraslih, predusem pa, ali vidijo tudi lastno usposabljanje kot del vloge in nalog, ki jic opravijajo kot izobrazevalci. Del tega, kako se izobrazujejo izobrazevalci odraslih v Sloveniji in kakšen jenthov odnos do lastnega strokovnega izobraževanja.

2 The International Council for Adult Education (ICAE) je globalna - mednarodna mrě̌a nevladnih organizacij, držav sveta ki je bila ustanovila leta 1973. V vlogi posvetovalnega telesa uradno sodeluje tudi z UNESCOM in Ekonomsko-socilnim svetom Združnih narodov (ECOSOC). Strateško zagovarja in promovira izobraževanje odraslih kot nepogresjyivo orodje pri ustrantianju demokratične oz. vključujoče družbe in dejavnega državljansto

\section{LITERATURA}

Birman Forjanič, Z., Đođević, N., Klemenčič, $S$, Možina, T., Orešnik Cunja, J., Vilič Klenovšek, T. izzivov, izobraževalne dejavnosti An in razvojni centra Slovenije: Izhodišč za oblikovanje nove zasnove andracoškega spopolnjevania Ljublian Andragoški center Slovenije. Pridobljeno 10.9. $2010 \mathrm{~s} \mathrm{http://izobrazevanje.} \mathrm{acs} \mathrm{si/razvojno.}$

European Association for The Education of Adults (junij 2009).Bonn: EAEA. Pridobljeno 7.9

Jelenc, Z. (1991). Terminologija izobraževanja odraslih: z gesli in pojasnili v slovenščini ter z ges Ljubljana: Pedagoški inšstitut.

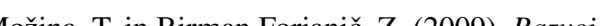
nožina, T. in Birman Forjaničc, Z. (2009). Razvoj delavcev - prikaz izsledkov vode andragoskih jubljan: Andragoški center Slovenije. Prido-

bljeno 10. 9. $2010 \mathrm{~s} \mathrm{http://izobrazevanje.} \mathrm{acs.si/}$ dokumenti/razvojno.

Research voor Beleid in PLATO (2008). Adult Learning Professit situation, trends and issuess. Final Report.

Leiden. European Commission. Pridoblieno 10.9. $2010 \mathrm{~s} \mathrm{http://ec} \mathrm{europa} \mathrm{eu/education/more-infor-}$ mation/.../adultprofreport_en.pdf.
Zakon o organizaciji in financiranju vzgoje in izobrazevanja. Ur. 1. RS, št. 16-718/2007.

Zalec, N. in Đorđević, N. (2009). Razvoj novih pristopov pri spopolnjevanju andragoških delavce - prikaz izsledkov fokusnih skupin. Ljubljana: Andragoški center Slovenije. Pridobljeno 10.9. $2010 \mathrm{~s}$ http://izobrazevanje.acs.si/dokumenti/ razvojno. 